\title{
The gift of blood in Europe: an ethical defence of EC directive 89/381
}

\author{
John Keown Queens' College, University of Cambridge
}

\begin{abstract}
Article 3.4 of EC directive 89/381 requires member states to take "all necessary measures to promote Community self-sufficiency in human blood or human plasma" and, for this purpose, to "encourage the voluntary unpaid donation of blood and plasma". This paper presents an ethical case in support of the policy of voluntary, unpaid donation.
\end{abstract}

\section{Introduction}

Recent newspaper stories about leaking blood bags, the increasing demand for blood as a result of more operations, the sale of surplus blood products to foreign countries and the reform of the blood transfusion service ${ }^{1}$ have raised vital questions about the most effective and ethical way of ensuring an adequate supply of blood and blood products. One major question is: "Is it ethical, in order to ensure an adequate supply of blood and blood products, to pay donors?"

European Community directive 89/381 requires member states to take "all necessary measures to promote Community self-sufficiency in human blood or human plasma" and, for this purpose, to "encourage the voluntary unpaid donation of blood and plasma". The ethical desirability of this policy appears to have been assumed rather than articulated, not least in the UK where there has been a dearth of political, public and ethical debate.

This paper, based on the author's contribution to an EC-funded research project into the ethics of the EC policy, ${ }^{2}$ presents an ethical case in favour of voluntary, unpaid donation. It comprises five arguments.

\section{Unnecessary}

First, paid donation is unnecessary. As the UK experience illustrates, a system of voluntary, unpaid donation can ensure an adequate supply to meet clinical demand. ${ }^{3}$

\section{Key words}

Blood; donation; paid/unpaid; European Community directive $89 / 381$.
But what if demand were to outstrip supply? Eve then, it appears that there is considerable scope for increasing supply within an unpaid system, whethsf by minimising the number of existing donors who lapse, or by recruiting new donors. Given that only an estimated 1.5 million people give blood annually, ${ }^{4}$ there is no shortage of potential ne recruits. But why should payment not be used te recruit and retain donors? The following argumentes suggest an answer.

\section{Altruism and social solidarity}

A major argument for exclusive reliance on unpa:ึ donation is that, unlike paid donation, it promotes altruism and social solidarity. Titmuss, in h landmark study of blood donation and social poliç, wrote that his study was, essentially, about "the rot of altruism in modern society". 5

This principle of unremunerated donation hæs lain at the heart of the UK National Blood Transfusion Service (now the National Bloof Authority) since its inception over half a century agg. The service depends heavily on donors' good will. As one NBTS leaflet for donors states, having listed tên "good things" that come out of blood:

"The 11th good thing that comes out of blood cannot be scientifically described, so we worf? attempt it. All the same, we want to take the oppors tunity of thanking you for it. It is called your goct will, and it happens to be the fuel that runs the NBTS". 6

Such altruism was evident during the summer $\AA_{f}$ 1995 after thousands of units were destroyed because of faulty bags. One journalist reported:

"The alarm provoked a typically British phenom non. In big cities and tiny villages a wave of Brition volunteering broke out and swamped the servise with blood".?

Remarking on the unselfish motivation of the vast majority of donors in a survey he conducted, Titmuss wrote: "Over two-fifths of all the answers in 
the whole sample fell into the categories 'Altruism', 'Reciprocity', 'Replacement' and 'Duty'. Nearly a third represented voluntary responses to personal and general appeals for blood. A further 6 per cent responded to an 'Awareness of Need'. These seven categories accounted for nearly $80 \%$ per cent of the answers, suggesting a high sense of social responsibility towards the needs of other members of society. Perhaps this is one of the outstanding impressions which emerges from the survey". 8

Similarly, in a survey reported in 1991, current and lapsed donors were asked why they gave blood. Their answers fell broadly into three categories. The first, "social conscience", was mentioned by $61 \%$ and the reasons given included helping others (34\%); doing the right thing $(17 \%)$; doing one's public duty $(11 \%)$, and benefiting the community $(5 \%)$. The second, "to fulfil need", was cited by $41 \%$ and reasons given included the fact that blood was needed ( $25 \%$ ); to help save lives $(11 \%)$; for accidents $(4 \%)$; for operations $(2 \%)$ and because the donor had a rare blood group (3\%). The final category, "personal benefit", was mentioned by $40 \%$ and included the reasons that the donor or his family might need blood (24\%); the donor's personal experience of transfusion $(8 \%)$; the satisfaction at helping $(4 \%)$; and the belief that it was healthy to donate (4\%). ${ }^{9}$ The survey indicates that altruism remains the primary motivation for donation.

To allow payment would not only encourage donation for non-altruistic motives, but might also discourage unpaid donation. Writing in 1973, Peter Singer concluded that the available evidence did indeed suggest that paying some people discouraged others from donating altruistically. This was supported both by the fact that in countries dependent on unpaid as opposed to paid donation, supply tended to keep up with increases in demand, and by the replies to Titmuss's questionnnaire. Singer observed:

"The nature of these replies - not the mere fact that the donors were altruistically motivated, but their attitudes toward the National Health Service in general and the Blood Transfusion Service in particular - is evidence that at least for some people the possibility of others buying and selling blood would destroy the inspiring force behind their own donations. At the same time, these replies enable us to understand why the existence of a commercial system could be expected to make a difference. The idea that others are depending on one's generosity and concern, that one may oneself, in an emergency, need the assistance of a stranger, the feeling that there is still at least this vital area in which we must rely on the good will of others rather than the profit motive - all these vague ideas and feelings are incompatible with the existence of a market in blood". 10
It seems reasonable to conclude that a significant number of donors who presently donate for altruistic reasons and reasons of social solidarity would cease to donate if payment were introduced. Those who are happy to give, and be seen to be giving, might well be reluctant to sell, or thought to be selling.

Finally, a move towards paid donation might also undermine feelings of altruism and social solidarity in the broader community. With increasing evidence of social disintegration and social isolation in British society and in the light of widespread concern about the growth of commercialisation, not least in the National Health Service, is there not a danger that paid donation could be, or at least could be perceived to be, a further instance of such trends? And might not paid donation then encourage further commercialisation at the expense of social solidarity? As Titmuss asked: "If blood is morally sanctioned as something to be bought and sold what ultimately is the justification for not promoting individualistic private markets in other component areas of medical care, and in education, social security, welfare services, child foster care, social work skills, the use of patients and clients for professional training, and other 'social service' institutions and processes"?'11 And it is noteworthy that those arguing for paid donation typically openly advocate the replacement of the "gift relationship" by impersonal market forces. ${ }^{12}$ Titmuss stressed that "the ways in which society organizes and structures its social institutions - and particularly its health and welfare systems - can encourage or discourage the altruistic in man; such systems can foster integration or alienation. ..". ${ }^{13}$

It seems that voluntary donation, rather than the market, is more likely to promote social integration and community. As Murray observes:

"Gifts to strangers affirm the solidarity of the community over and above the depersonalizing, alienating forces of mass society and market relations. They signal that self-interest is not the only significant human motivation. And they express the moral belief that it is good to minister to fundamental human needs, needs for food, health care, and shelter. . . . These universal needs irrevocably tie us together in a community of needs, with a shared desire to satisfy them, and see them satisfied in others". ${ }^{14}$

He adds that purely economic analyses of blood procurement ask the wrong question: "We should not inquire: 'How can we obtain the most blood at the least cost?' but 'What sort of society do we want?' ". ${ }^{15}$

As for encouraging altruism, Singer's view that altruism is a virtue which increases the more it is practised is surely more plausible and persuasive than Arrow's economically-based notion of individuals possessing a fixed quantity of altruism which diminishes the more it is spent. The old maxim that an act tends to become a habit and a habit tends to 
form a character seems apt. An individual who acts altruistically tends thereby to develop an altruistic character and becomes more rather than less disposed to act altruistically. It is all too obvious that the same holds in relation to the person who performs selfish acts: the person who (say) steals other people's property tends thereby to develop a rapacious character. It is puzzling why those who would presumably experience little difficulty in accepting the proposition that a person who steals once is more rather than less likely to steal again, should baulk at the notion that a person who gives is more rather than less likely to give again. In short, acts of altruism promote further acts of altruism in that they tend to reinforce altruistic dispositions.

A counter-argument in favour of a move to paid donation is that donors motivated by altruism and community solidarity could still donate under a paid system; they would not have to accept payment. This argument may be factually correct but overlooks the change in the character of the system which could well result from the introduction of remuneration. It seems reasonable to surmise (as, evidently, do those most closely involved in the NBTS) that a significant proportion of voluntary donors would wish to have no part of a system which bought blood or plasma.

But, it may be argued, even if significant numbers of voluntary donors did withdraw, any shortfall could readily be made up by paid donors. This may well be so but, even if true, and leaving aside the likely loss of altruism and social solidarity, would the use of paid donors not compromise the quality of blood and risk human exploitation? To these concerns we now turn.

\section{Safety}

Given that payment exercises a greater pull on the poor than the rich, that the poor tend to be less healthy, and that they have a financial interest in concealing any ill-health, it is unsurprising that donations from paid donors tend to be less safe than those from unpaid donors. As the cellular components of blood cannot be virally inactivated, and tests for infection are not completely reliable, safety favours unpaid donation.

However, plasma products can be virally inactivated, and it is widely accepted that plasma products manufactured by reputable commercial companies from paid donor plasma are as safe as products made from unpaid donor plasma. The evidence indicates that although plasma from paid donors tends to be less safe than that from unpaid donors, whether the donor is paid is only one element in the safety equation. Other elements, including donor screening and viral inactivation procedures are no less important in ensuring the maximum safety of plasma products. Plasma products which are derived from paid and well-screened donors and which are subjected to effective viral inactivation procedures are likely to be much safer than plasma from unpaid a poorly-screened donors which is not virally inact? vated. In other words, non-payment no mog ensures safety than payment precludes safety. ${ }^{16}$

However, as Piet Hagen concludes: "If propEr selection is carried out, the unpaid donor population is likely to be healthier than the paid donor popule tion". ${ }^{17}$ And Van Aken's review of the evidence $\operatorname{cog} 8-$ cludes: "What is clear, and irrefutable on the basis $8 \mathrm{f}$ published evidence, is that the ... tests in the con mercial sector define a population which clearly represents a greater risk to potential recipients" os Further, however effective viral deactivaction ma currently be, there is always the risk of error. Thepe is also the risk of hitherto undiscovered viruses. $\mathrm{HAd}$ is a case in point: it was not absent from voluntaity donor plasma but the heaviest contamination was commercial plasma. More recently, concern h\&s been raised about possible transmission by transfusion of Creutzfeldt-Jakob disease.

The argument from safety would, therefore, appear to apply not only to whole blood, but ever albeit less forcefully, to plasma products. It seems, therefore, that on grounds of safety the more prudent policy is to encourage blood and bloof products from unpaid donors.

\section{Exploitation}

A further argument is that the use of paid blood $\overrightarrow{\text { or }}$ plasma donors involves a significant risk of exploining the poor and socially disadvantaged. The finat cial remuneration will act as a far more powerful inducement to the poor than the rich. This objection is, of course, related to the issue of safety for, as his been well documented, the poor tend to be in worse state of health than the affluent. Titmuss graphically illustrated this objection in relation to some blood collection centres in the US which used many from "Skid-Row". Referring to unethicall experimentation and plasmapheresis, he observed:

"In these expanding fields of human experiment tion - as with plasmapheresis programs - virtually ady the strangers who give, by inducement, for money of in captive situations, are poor people; the indigent, the deprived, the educationally handicapped, the socially inadequate (in and out of prisons and other institutions), and all those described by an American sociologist as 'inept' in advancing the hypothesis thit modern economic systems 'utilize the inept moä efficiently". ${ }^{19}$

A counter-argument is that Titmuss was writing over twenty years ago about a country where, unlike now, paid blood donation was commonplace, and that the danger of exploitation is one which can be mis imised. However, one survey involving almosit 10,000 paid plasma donors revealed that over $30 \%$ had donated more than 18 times over a period of 
only three months. ${ }^{20}$ Frequent red-cell donations endanger health by inducing iron deficiency and its consequences and there is also concern about the possible risks of frequent plasma donation.

The risk of exploitation is clearly real and, however scrupulous reputable companies are in seeking to guard against it, cannot be ignored in deciding whether, as a matter of social policy, to discourage paid blood and plasma donation. And however minimal the risk might be in a system run by a reputable company and closely inspected by regulatory authorities, the risk of abuse remains, even in a first-world country such as the US, let alone less developed nations.

Moreover, if paid donation were condoned by the EC, there is a surely a danger that this might encourage less developed countries to embark (or continue) on the path of paid donation, with the consequent risk of widespread and serious exploitation. Might this not produce the objectionable situation where citizens of poorer nations are used as a resource to supply the needs of citizens of wealthier nations? Or even the grotesque scenario where citizens of poorer nations cannot afford to buy their own blood? In 1975 the World Health Assembly expressed serious concern that the activities of private companies seeking to establish paid blood and plasma centres in developing countries might interfere with efforts to establish national transfusion services based on unpaid donation. ${ }^{21}$

\section{Commercialisation of the human body}

To the extent that paying donors for their blood tends to treat (or could be perceived as treating) a part of the human body as property, it arguably devalues the human body. Do not the buyer and seller, and the community which endorses (and legally enforces) such a transaction, inevitably depersonalise the human body and treat it as something suited for commercial exchange? If so, does this not promote an instrumental view of human beings, as means rather than as ends, as moral and legal objects rather than subjects? Does it not encourage a perception of the donor, by others and by him or herself, as a source of raw material to be exploited? Might this not, moreover, open up disturbing possibilities of treating other bodily parts as chattels? Titmuss feared so: "If blood is considered in theory, in law, and is treated in practice as a trading commodity then ultimately human hearts, kidneys, eyes and other organs of the body may also come to be treated as commodities to be bought and sold in the marketplace". ${ }^{22}$

A counter-argument may be that, while such ethical objections are valid in relation to human beings and human organs, they are invalid in relation to renewable parts of the body. Who, it may be argued, would object to the sale of hair or urine? But is blood (an organ, albeit renewable) not more analagous to a kidney, the sale of which is illegal, than to urine? Murray makes the point that whereas the sale of urine or hair would be unlikely to cause a great moral outcry, such products are "less central to what characterizes living human persons, members of the human community" than organs and blood. He adds: "In any case, the nature of the gift, its meaning and significance within the community, will determine whether it belongs to the realm of commodities or the circle of gifts". ${ }^{15}$ Although blood is a renewable bodily product, it is surely invested by the community with an undeniably special symbolic significance, and the social and moral meaning of donating blood - the altruistic donation of a life or health-saving gift from one person to another - is entirely different from the alienation of waste products such as urine.

\section{Conclusions}

There would appear to be at least five sound reasons for discouraging, as a matter of social policy, paid donation of blood and plasma. Some of the reasons are not, perhaps, individually sufficient to require the adoption of such a policy, particularly in relation to developed countries such as the $\mathrm{UK} .{ }^{23}$ It is suggested, however, that cumulatively the five arguments (which, in any event, are inter-related) build a persuasive case in favour of the adoption of the principle of voluntary unpaid donation as a matter of EC social policy.

That policy should be based not only on a coherent account of why unpaid donation is ethically preferable but should also include a defensible and workable definition of "unpaid" donation, such as the following:

"A donation is considered voluntary and non-remunerated if the person gives the blood, plasma or cellular components of his/her own free will and receives no payment for it, either in the form of cash or in kind which could be considered a substitute for money. This would include time off work other than that reasonably needed for the donation and travel. Small tokens, refreshments and reimbursements of direct travel costs are compatible with voluntary, non-remunerated donation". ${ }^{24}$

While it may be easy to identify clear cases of "paid" and "unpaid" donation, there will be borderline cases. While, on the one hand, the payment of $£ 25$ to every donor would clearly amount to payment, and while, on the other, the provision of tea and biscuits clearly would not, there are bound to be middle cases. For example, the provision of a meal could amount to remuneration. Whether it did would depend on the circumstances: is it a meal which the donor would otherwise miss because of his trip to the donor centre? Or is it a meal which is provided to all, regardless of circumstances? What is 
important is that payment, and anything that is likely to be perceived by the reasonable person as payment, should be discouraged lest the principle of unpaid donation be jeopardised. The definition should be formulated to ensure that people donate out of altruism and are not induced to donate by the prospect of remuneration. While recompense falls on the acceptable side of the line, reward does not.

The service in Britain appears to observe the principle scrupulously. Neither the provision of tea and biscuits after donation; the (exceptional) reimbursement of travel expenses; the time off work to donate which some employers grant employees, nor the awarding of certificates, plates or mugs to mark a certain number of donations, breaches the principle.

Even were it more expensive to use unpaid donors (given the cost of recruiting and keeping volunteers), is the promotion of altruism and social solidarity not worth the expense? As Titmuss commented:

"no money values can be attached to the presence or absence of a spirit of altruism in a society. Altruism in giving to a stranger does not begin and end with blood. It may touch every aspect of life and affect the whole fabric of values". ${ }^{25}$

In short, if the ethical case is persuasive, unpaid donation is something worth paying for.

Fohn Keown, MA, DPhil, is Lecturer in the Law and Ethics of Medicine, Faculty of Law, University of Cambridge and Fellow and Tutor, Queens' College, Cambridge.

\section{References and notes}

1 See for example, Deer J. For love or money? The Sunday Times Magazine 1995 Oct 8: 46-55.

2 Institute for Bioethics. Marketing blood? Maastricht: Institute for Bioethics, 1994.

3 An internationally accepted definition of "self-sufficiency" is "the provision of blood and blood products from within a population to satisfy the clinical needs of that population". However, the UK has opted for a more relaxed definition of "self-sufficiency" as the provision of a sufficient range and quality of domestically-sourced blood products to meet the needs of all patients whose clincians prefer these to other products. Van Aken WG. The collection and use of human blood and plasma in Europe. Report prepared for the Council of Europe and the Commission of the European Communities. Brussels: EC Commission, 1992: 22. The reason for this wider definition - of satisfying clinical demand rather than clinical need - is respect for doctors' clinical freedom to prescribe the product of their choice, even if imported from outside the EC and derived from paid donation.

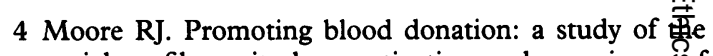
social profile, attitudes, motivation and experience ofof donors. Transfusion Medicine 1991; 1: 201.

5 Titmuss RM. The gift relationship. New York: Vint尔e Books Edition, 1972: 12.

6 National Blood Transfusion Service. Eleven goळबd things that come out of blood. 1148A.

7 See reference 1: 46 .

8 See reference 5: 235-6.

9 See reference 4: 205 table 4.

10 Singer P. Altruism and commerce: a defence $\overrightarrow{\otimes f}$ Titmuss against Arrow. Philosophy and Public Affatirs 1973; 2: 315 . (Original emphasis).

11 See reference 5: 12.

12 See for example, Arrow KJ. Gifts and exchanges Philosophy and Public Affairs 1972; 1: 355; Stewart R. Morality and the market in blood. Fournal of Applied Philosophy 1984; 1: 227.

13 See reference 5: 225.

14 Murray TH. Gifts of the body and the needs gof strangers. Hastings Center Report 1987; 17: 35.

15 See reference 14: 37 .

16 See: The quality and safety of plasma used in the manufacture of blood products. Eastbourne: Armour Pharmaceutical Co Ltd.

17 Hagen PJ. Blood transfusion in Europe: a "white paper". Strasbourg: Council of Europe Press, 1993: 124.

18 Van Aken WG. Gift or good? Vox Sang 1992; 63:?

19 See reference 5: 219-220. For two contrasting perspe्ctives on developments in the US see Eckert R. Wallace EL. Securing a safer blood supply: two vieß্কs. Washington: American Enterprise Institute, 1985.

20 Paull NB. Safeguarding donors: first, do no har Fournal of the American Blood Resources Association 19\$3; Spring: 11, table 4 .

21 World Health Assembly. Resolution WHA28. Utilization and supply of human blood products, Genezia, 1975. The General Assembly of the International Society of Blood Transfusion, at its XVIth congress in Montrgal in 1980 , reaffirmed its policy of self-sufficiency a 2 d stated in its code of ethics: "Financial profit must neyer be a motive either for the donor or for those responsiBle for collecting the donation. Voluntary non-remunerated donors should always be encouraged". At its XXIRd conference in Tehran in 1973, the Red Cross declaredits belief that the "non-remunerated donation of blood i a nationwide non-commercial blood service produces safest medical therapy and strengthens a nation's soêl structure through the value it places on this freely chosen individual act of humanitarian service" and urged hall governments to provide a safe blood service on the bagis of unremunerated donation.

22 See reference 5: 158 .

23 For critiques of Titmuss's arguments for unpक्किid donation see Plant R. Gifts, exchanges and the political economy of health care. Fournal of Medical Ethics 19747; 3: 166-173; Plant R. Gifts, exchanges and the politieal economy of health care. Part II. How should heqh care be distributed? 1978; 4: 5, and del Pozo It:R. Paying donors and the ethics of blood supply. Fournafof Medical Ethics 1994; 20: 31-5.

24 See reference 3: 22.

25 See reference 5: 198 . 